\title{
Primary Subcutaneous Cyst Hydatid: Presentation of Two Cases
}

\author{
Primer Subkutan Kist Hidatik : İki Olgu Sunumu
}

\author{
Serden Ay, Ahmet Okuş, Recep Demirgül, Mehmet Ali Eryılmaz, Arif Atay \\ Department of General Surgery, Konya Education and Research Hospital Konya, Turkey
}

\begin{abstract}
Subcutaneous localization of an hydatid cyst is quite rare, and is found in literature in the form of case presentations. Other points worthy of attention are the lack of other foci in the majority of these cases, and the negative results of serology. In this study, two primary subcutaneous hydatid cyst cases, one in the facial area (53-year old female) and the other on the back (37-year old female), have been examined with reference to literature. In both cases, no other foci were determined, and the hydatid cyst serology was negative. When these two cases and the cases in literature are studied, it can be said that the hydatid cyst grows faster than previously known. It is noteworthy that, generally, in atypically localized cyst hydatids, there are no other foci (liver and lungs) and the serology is negative. This shows that the etiopathogenesis of the disease is not fully understood as yet. (Turkiye Parazitol Derg 2013; 37: 219-21)
\end{abstract}

Key Words: Hydatid cyst, subcutaneous tissue, Echinococcus granulosus

Received: 30.11 .2012

Accepted: 11.04.2013

\section{ÖZET}

Kist hidatiğin subkutan yerleşimi oldukça nadirdir ve literatürde olgu sunumları şeklinde yer almaktadır. Bu olguların çoğunda başka bir odak olmaması ve serolojinin negatif olması diğer dikkat çekici bir durumdur. Bu çalışmada biri yüzde (53 yaşında bayan) diğeri ise sırtta (37 yaşında bayan) subkutan yerleşimli iki primer kist hidatik olgusu literatür gözden geçirilerek irdelenmiştir. Her iki olguda da başka bir odak tespit edilmemiştir ve kist hidatik serolojisi negatiftir. Atipik lokalizasyonlu kist hidatiklerde seroloji genelde negatif olmaktadır. Bizim sunduğumuz olgularda ve literatürdeki olgu sunumları incelendiğinde serolojinin çoğu olguda negatif olduğu gözlenmektedir. Diğer taraftan atipik lokalizasyondaki kist hidatiklerde vücudun diğer taraflarında genelde kist hidatik tespit edilmemektedir. Bu iki olgu ve literatürdeki olgular irdelendiğinde kist hidatiğin bilinenden daha hızlı büyüdüğü söylenebilir. Atipik lokalizasyonlu kist hidatiklerde genelde başka bir odağın (karaciğer ve akciğer) olmaması ve serolojinin negatif olması dikkat çekicidir. Bu da hastalığın etyopatogenezinin halen tam aydınlatılamadığını göstermektedir. (Turkiye Parazitol Derg 2013; 37: 219-21)

Anahtar Sözcükler: Kist hidatik, subkutan doku, Echinococcus granulosus

Geliş Tarihi: 30.11 .2012

Kabul Tarihi: 11.04.2013

\section{INTRODUCTION}

Hydatid cyst is a disease caused by the larvae of the parasite Echinococcus, endemic to certain regions and still seen quite often. The disease is mostly seen in the liver and lungs. However, it can be observed in many other organs of the body, although not very often (1).
Subcutaneous localization of an hydatid cyst is quite rare, and can be seen in the literature only as case presentations. In most of these cases, the lack of any other foci, and the negative results of serology are other points of note (2).

In this study, two subcutaneously localized primary cyst hydatid cases, one in the face and the other on the back, have been examined with reference to the literature.

Address for Correspondence/ Yazışma Adresi: Dr. Serden Ay, Department of General Surgery, Konya Education and Research Hospital Konya, Turkey Phone: +903323236709 E-mail: serdenay@yahoo.com doi:10.5152/tpd.2013.49 


\section{CASE REPORTS}

Written informed consent was obtained from the patients who participated in these cases.

\section{Case 1}

A fifty-three-year old female patient applied to our hospital with complaints of a swelling and pain which had started 1 week earlier in front of the left ear. Physical examination showed a $4 \times 2 \mathrm{~cm}$, smooth contoured, mobile mass in the temporomandibular area in front of the ear. A subcutaneous cystic lesion of 40x15 mm was observed in the upper area of the left ear in the superficial tissue ultrasonography.

The mass was excised under local anesthesia. The excised mass was macroscopically in conformance with an hydatid cyst. Germinative membrane was removed whole and in its entirety (Figure 1). In the microscopic examination of the slides prepared from the material, the cuticular membrane dyed purple-violet with HE and PAS, and scolexes on one area of the membrane. Laboratory values were normal and t hydatid cyst serology was negative (cyst hydatid specific lg E). Further examination did not reveal any other hydatid cyst foci.

\section{Case 2}

A thirty-seven-years old female patient applied with complaints of a swelling in the back which started approximately 1 month earlier, grew with time and was causing intermittent pain. In her physical examination, a stiff, mobile $10 \times 10 \mathrm{~cm}$ mass with smooth contours was palpated adjacent to the left scapula. Superficial tissue ultrasonography showed a smooth contoured, thick walled subcutaneously limited cystic lesion of approximately $12 x$ $10 \times 7 \mathrm{~cm}$ on the outer side of the left scapula.

The mass was excised under local anesthesia. Macroscopic examination showed a cystic lesion with a germinative membrane. On further examination, hydatid cyst serology was found to be negative. No pathological indications of hydatid cyst were observed in the lung graphs and abdominal ultrasonography.

Hydatid cyst was not considered before excision in both cases. The cases were started on albendazole $(10 \mathrm{mg} / \mathrm{kg})$ after the excision. The patients, currently under observation after 6 months, have no complaints.

\section{DISCUSSION}

Echinococcus granulosus, the cause of hydatid cyst, is a parasite living in the intestinal tract of animals such as the dog and wolf. The eggs, expelled by the dog's feces, infect particularly grazing intermediate hosts such as sheep, goats and cattle. Humans are an uncommon intermediate host for hydatid cysts. The embryos that hatch in the intestines of the intermediate host pass into the liver through the portal vein, and sometimes through this way into the lungs, to settle there. Embryos that pass through the filters in these two organs can settle in other organs of the body $(1,2)$.

The hydatid cyst was thought to be a slow growing lesion. Many sources cite thehydatid cystas growing $1 \mathrm{~cm}$ a year in humans, while other studies disclose a yearly growth of $4-5 \mathrm{~cm}(3,4)$. However, it has recently been determined that the rate of growth is faster than previously known (1). When the complaint periods of the cases with atypical localizations in literature are examined, it can be seen that they are short, similar to our cases. This gives rise to the consideration that hydatid cysts can grow very rapidly $(5,6)$.

The development of hydatid cysts outside the liver or lungs may be primary or secondary (7). Primary subcutaneous hydatid cyst is rare even in endemic areas. Literature discloses the prevalence of subcutaneous hydatid cyst as $2 \%$ of all hydatid cysts $(8,9)$.

In the literature, there is only one reported case of hydatid cyst in the facial area (10). Ok et al. (9), have described a primary hydatid cyst case in the submandibular region. In our first case, a subcutaneous hydatid cyst was located in front of the left ear. Further examination showed no other foci.

Literature reports that a subcutaneous hydatid cyst is seen in many parts of the body, most frequently in the femoral and gluteal areas, in the form of case presentations (11). In our second case there is a primary subcutaneous hydatid cyst adjacent to the left scapula. No other primary foci were determined in this case, either.

Serology is usually negative in hydatid cysts with atypical localizations (2). In the cases we have presented, and when the case presentations in the literature are studied, in most of the cases, it is seen that serology is negative. On the other hand, in hydatid cysts with atypical localizations, usually no hydatid cysts are found in other parts of the body (2).

\section{CONCLUSION}

When these two cases and the cases in the literature are studied, it can be said that thehydatid cyst grows faster than previously

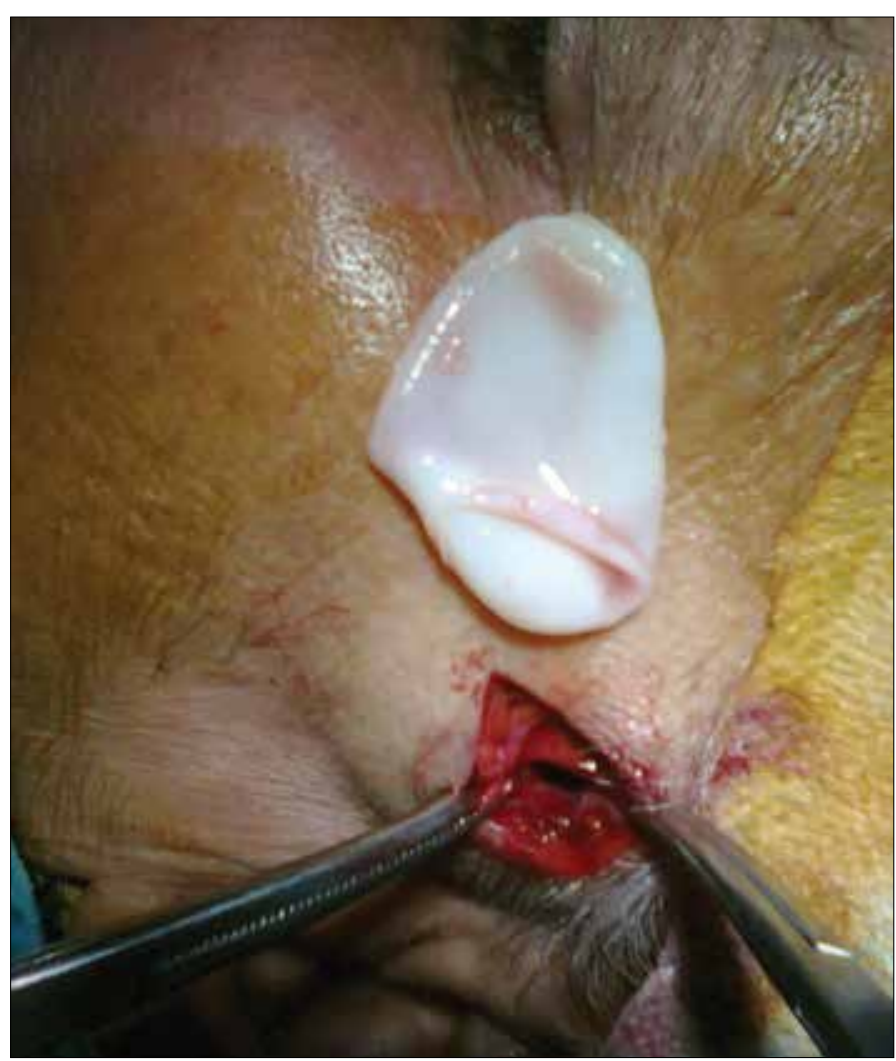

Figure 1. Germinative membrane of the cyst 
known. It is noteworthy that, generally in atypically localized hydatid cysts, there are no other foci (liver and lungs) and the serology is negative. This shows that the etiopathogenesis of the disease is not fully understood as yet.

\section{Conflict of Interest}

No conflict of interest was declared by the authors.

Peer-review: Externally peer-reviewed.

Informed Consent: Written informed consent was obtained from patients who participated in this case.

\section{Author Contributions}

Concept - S.A.; Design - A.O.; Supervision - M.A.E.; Materials S.A.; Data Collection and/or Processing - R.D.; Analysis and/or Interpretation - H.Ş.; Literature Review - S.A., A.O., A.A.; Writer - S.A., A.O.; Critical Review - M.A.E.

\section{Çıkar Çatışması}

Yazarlar herhangi bir çıkar çatışması bildirmemişlerdir.

Hakem değerlendirmesi: Dış bağımsız.

Hasta Onamı: Yazılı hasta onamı bu olguya katılan hastalardan alınmıştır.

\section{Yazar Katkıları}

Fikir - S.A.; Tasarım - A.O.; Denetleme - M.A.E.; Malzemeler S.A.; Veri toplanması ve/veya işlemesi - R.D.; Analiz ve/veya yorum - H.Ş.; Literatür taraması - S.A., A.O., A.A.; Yazıyı yazan S.A., A.O.; Eleştirel Inceleme - M.A.E.

\section{REFERENCES}

1. Terblanche J, Krige JEJ. Karaciğer Ekinokokkozu. Current Surgical Therapy sixth edition Philadelphia 2001; 324-9.

2. Demirel AH, Akgün A, Öngören AU, Kısakürek M, Erol MF. Atipik Lokalizasyonlu Kist Hidatikler. Akademik Gastroenteroloji Dergisi 2007; 6: 158-60

3. Von Lichtenberg F. Pathology of infectious diseases. Raven Press New York 1991: 331-5.

4. Miman Ö, Atambay M, Aydın NE, Daldal N. Kistik Ekinokokkozis Nedeniyle Opere Edilmiş 91 Olguda Klinik, Morfolojik ve Serolojik Irdelemeler. Türkiye Parazitol Derg 2010; 34: 179-83.

5. Battyany I, Andrea L, Nagy KK. Subcutaneous hydatid cyst in the popliteal fossa at the site of a previous wasp sting. Diagn Interv Radiol 2011; 17: 163-5.

6. Eryılmaz MA, Eroğlu C, Karabağlı P, Çobankaya OE. Gluteal Hydatid Cyst: Case Report. Türkiye Klinikleri J Med Sci 2010; 30: 1380-3.[CrossRef]

7. Ölmez A, İtik V, Aydın C, Kayalp C. Primary subcutaneous hydatid cyst: at the flank a case report. Eur J Surg Sci 2010; 1: 93-5.

8. Kouskos E, Chatziantoniou J, Chrissafis I, Anitsakis C, Zamtrakis S. Uncommon locations of hydatid cysts. Singapore Med J Case Report 2007; 48: 119-21.

9. Ok E, Sözüer E M. Solitary subcoutaneous hydatid cyst : a case report. Am J Trop Med Hyg 2000; 62: 583-4.

10. Oztürk S, Devec M, Yildirim S. Hydatid cyst in the soft tissue of the face without any primary. Ann Plast Surg 2001; 46: 170-3.[CrossRef]

11. Kayaalp C, Dirican A, Aydin C. Primary subcutaneous hydatid cysts: a review of 22 cases. Int J Surg 2011; 9: 117-21.[CrossRef] 